\title{
Experimental Study on Mushroom Yield of Commercial Strains from Pleurotus ostreatus Cultivated on Rice Straw in Mexico
}

\author{
Maricela Cayetano-Catarino
}

Teodoro Bernabé-González

Gadiel Bernabé-Villanueva

Adalid Romero-Flores

Higher School of Natural Sciences

Autonomous University of Guerrero

Mexico

\section{Daniel Martínez-Carrera}

College of Postgraduates in Agricultural Sciences (CP)

Campus Puebla, Biotechnology of Edible

Functional and Medicinal Mushrooms

Mexico

\begin{abstract}
Four commercial strains of Pleurotus ostreatus were cultivated at the pilot plant level on rice straw as substrate. In all strains, three harvest were obtained, except in one that only presented two, in a period of 41 to 59 days. The parameters evaluated were days in the formation of fruiting primordia, the pileus diameter (three groups G1: $<5$ $\mathrm{cm}$; G2: of 5 to $9.9 \mathrm{~cm}$; G3: >10 cm), biological efficiency $(B E)$, yield $(Y)$ and production rate (PR). Strains CP281 and $C P-753$ showed the highest production with $261.1 \%$ and $240.6 \%$ of BE, $60 \%$ and $55.3 \%$ of $Y$, 5.2\% and $5.8 \%$ of $P R$, respectively. Next, CP-245 strain showed $213.3 \%$ of BE, $49 \%$ of $Y$ and $3.8 \%$ of PR. Lower production was presented on CP-50 strain (EB 170.9\%, Y 39.3\% and PR 4.2\%). The fours trains can be cultivated in small or large scale in several regions of Mexico.
\end{abstract}

Keywords: Mushroom cultivation, agricultural wastes, edible mushroom.

\section{Introduction}

Pleurotus spp., is one group of edible mushrooms cultivated commercially, which rank second worldwide (Royse et al., 2017). In Latin America, commercial production is generated mainly in Brazil, Mexico, Colombia, Argentina and Guatemala (Royse and Sanchez, 2017). In Mexico, mushroom production (Pleurotus spp.) is $4.76 \%$, of total production (Martínez-Carrera et al., 2016). In the cultivation most strains of foreign origin which are adapted to grow on different substrates have mostly be used. Therefore, it is important to know strains that can be incorporated and adapted into the cultivation of edible mushroom in different regions of Mexico to obtain higher yields. In this study, we evaluated the production at the pilot plant level of four commercial strains of Pleurotus ostreatus, using rice straw (Oryza sativa) as a substrate.

\section{Materials and methods}

\subsection{Strains and spawn}

CP-245, CP-281, CP-753 and CP-50 strains of P. ostreatus were studied, which are deposited at the Genetic Resources Unit of Edible, Functional and Medicinal Mushrooms (CREGENHCFM), College of Postgraduates Campus Puebla, Mexico. They were maintained on potato dextrose agar (PDA, Difco) and incubated at $27^{\circ} \mathrm{C}-$ $28^{\circ} \mathrm{C}$. Spawn was prepared on wheat grains (Triticum aestivum), sterilized at $121^{\circ} \mathrm{C}$ for $1 \mathrm{~h}$ in polypropylene bags (ca. $250 \mathrm{~g} / \mathrm{bag}$ ) and inoculated with $1 \mathrm{~cm}^{2}$ of PDA with mycelium developed from each strain. Inoculated bags were incubated at $27^{\circ} \mathrm{C} \pm 2^{\circ} \mathrm{C}$ for two weeks in darkness.

\subsection{Substrate preparation and spawning}


Rice straw was cut into 5 to $6 \mathrm{~cm}$ lengths and soaked in water for $18 \mathrm{~h}$ and pasteurized by immersion in hot water at $80^{\circ} \mathrm{C}$ for $1 \mathrm{~h}$. Once cold, it was placed into polypropylene bags $(40 \mathrm{x} 60 \mathrm{~cm})$ with $1.5 \mathrm{~kg}$ fresh weight per bag and spawned ( $c a .100 \mathrm{~g}$ inoculum). The moisture content of the substrate was $77 \%$. Ten samples were prepared for each strain.

\subsection{Incubation and crops}

Inoculated bags were incubated at $25^{\circ} \mathrm{C}-28^{\circ} \mathrm{C}$ in the dark. When the first primordia appeared they were transferred to the production room and placed on metal shelves, then the plastic was removed and the environmental conditions went from $76 \%-85 \%$ of relative humidity, $25^{\circ} \mathrm{C}-27^{\circ} \mathrm{C}$, with day light conditions through windows.

Productivity was based on the number of days until primordia formation, biological efficiency (BE, fresh weight of mushrooms/dry weight substrate x 100), mature basidiocarps yield (Y) (fresh weight of mushrooms/fresh weight substrate $\mathrm{x} 100)$, production rate ( $\mathrm{PR}, \mathrm{BE} / \mathrm{total}$ days of production). Basidiocarps were classified according to the diameter of pileus: group $1(\mathrm{G} 1)<5 \mathrm{~cm}$, group 2 (G2) from 5 to $9.9 \mathrm{~cm}$ and group $3(\mathrm{G} 3)>10 \mathrm{~cm}$ (GaitánHernández and Silva, 2016).

\section{Experimental design and statistical analysis}

A completely random design was used. Data were processed by an analysis of variance and the average values were analyzed using Tukey's multiple range test $(\alpha=0.05)$.

\section{Results and discussion}

Rice straw was a suitable substrate for fruiting of the four strains, which presented the first fruiting primordia between 15 and 45 days after spawning. The production cycle was between 41 and 59 days. In the size of the pileus, the percentages were for G1 between $18.9 \%$ and $50.9 \%$, for $\mathrm{G} 2$ between $43 \%$ and $56.1 \%$, and for G3 between $4.8 \%$ and $25 \%$ (Table 1).

Table 1. Formation of primordia, total cultivation cycle (days) and the averages of mushroom production by size Group (percentage in parentheses) obtained by four P. ostreatus strains cultivated on rice straw.

Appearance of primordia

(days after spawning) Groups by size of the pileus $(\mathrm{g})$

\begin{tabular}{|c|c|c|c|c|c|c|c|}
\hline Strains & $1 \mathrm{st}$ & 2nd & $3 \mathrm{rd}$ & $\mathrm{TCC}^{1}$ & $\mathrm{G}^{2}$ & $\mathrm{G} 2$ & G3 \\
\hline CP-245 & $40-45$ & $50-57$ & 0 & $54-59$ & $267.7(36.3) b^{*}$ & $316(43) b c$ & $152.1(20.7) \mathrm{ab}$ \\
\hline CP-281 & $20-23$ & $30-31$ & $42-48$ & $47-53$ & $458.7(50.9) \mathrm{a}$ & $399.4(44.3) \mathrm{ab}$ & $42.8(4.8) \mathrm{b}$ \\
\hline CP-753 & $16-18$ & $27-31$ & $37-40$ & $42-45$ & $156.8(18.9) \mathrm{c}$ & $465.9(56.1) \mathrm{a}$ & $207.2(25) \mathrm{a}$ \\
\hline CP-50 & $15-19$ & $24-29$ & $36-39$ & $41-44$ & $270.2(45.9) b$ & $269.5(45.7) b$ & $49.7(8.4) b$ \\
\hline
\end{tabular}

${ }^{1} \mathrm{TCC}=$ total crops cycle

${ }^{2} \mathrm{G} 1$ : $<5 \mathrm{~cm}$; G2: of 5 to $9.9 \mathrm{~cm}$; G3: $>10 \mathrm{~cm}$.

*Different letters in the same column indicate statistical differences between mean values according to Tukey's multiple range test $(\alpha=0.05)$.

Three harvests in each strain was obtained, except one strain that only presented two, with total average values between $589.4 \mathrm{~g}$ and $900.9 \mathrm{~g}$. The values obtained in each strain ranged from $170.9 \%$ to $261.1 \%$ of BE, $39.3 \%$ to $60 \%$ of Y and $3.8 \%$ to $5.8 \%$ of PR (Table 2).

Table 2. Distribution of total averages in mushroom production (g) (percentage in parentheses) and evaluation of the productivity achieved by four $P$. ostreatus strains.

Harvests (g)

Productivity indices

\begin{tabular}{llllllll}
\hline Strains & \multicolumn{1}{c}{ 1st } & \multicolumn{1}{c}{ 2nd } & \multicolumn{1}{c}{ 3rd } & \multicolumn{1}{c}{ Total $(\mathrm{g})$} & \multicolumn{1}{c}{ BE\% } & Y\% & PR\% \\
\hline CP-245 & $621.8(84.5) \mathrm{a}^{*}$ & $114.1(15.5) \mathrm{c}$ & $0 \mathrm{c}$ & $735.9 \mathrm{~b}$ & $213.3 \pm 23 \mathrm{~b}$ & $49 \pm 5.3 \mathrm{~b}$ & $3.8 \pm 0.5 \mathrm{~b}$ \\
CP-281 & $573.3(63.6) \mathrm{a}$ & $233.5(25.9) \mathrm{a}$ & $94.2(10.5) \mathrm{a}$ & $900.9 \mathrm{a}$ & $261.1 \pm 21 \mathrm{a}$ & $60 \pm 4.8 \mathrm{a}$ & $5.2 \pm 0.4 \mathrm{a}$ \\
$\mathrm{CP}-753$ & $606.4(73) \mathrm{a}$ & $165.8(20) \mathrm{b}$ & $57.7(7) \mathrm{b}$ & $829.9 \mathrm{ab}$ & $240.6 \pm 35 \mathrm{ab}$ & $55.3 \pm 8 \mathrm{ab}$ & $5.8 \pm 0.9 \mathrm{a}$ \\
\hline $\mathrm{CP}-50$ & $374.1(63.5) \mathrm{b}$ & $139.4(23.6) \mathrm{bc}$ & $76(12.9) \mathrm{ab}$ & $589.4 \mathrm{c}$ & $170.9 \pm 30 \mathrm{c}$ & $39.3 \pm 7 \mathrm{c}$ & $4.2 \pm 0.8 \mathrm{~b}$ \\
\hline BE = biological efficiency & & & & & \\
Y= yield \\
PR = production rate \\
*Different letters in the same column indicate statistical differences between mean values according to Tuke's multiple range \\
test $(\alpha=0.05)$.
\end{tabular}


There are no comparative records on production in CP-245, CP-281 and CP-753 strains. CP-50 strain has been cultivated in Mexico on several agricultural residues such as wheat straw (Triticum aestivum), barley straw (Hordeum vulgare), bean straw (Phaseolus vulgaris), corn stubble (Zea mays), dehydrated coffee bagasse (Coffea arabica), and dehydrated alfalfa (Medicago sativa) as a supplement in several agricultural residues already mentioned, reaching $\mathrm{BE}$ between $62.71 \%$ and $179.4 \%$, PR between $0.3 \%$ and $1.9 \%$, with total production cycle between 62 to 95 days at $26^{\circ} \mathrm{C}-28^{\circ} \mathrm{C}$ (Romero-Arenas et al., 2013; 2018).

The values obtained on the four strains are highly superior to those recorded with other Pleurotus strains on rice straw, such as P. ostreatus (BE 55.0\%, 92.1\% and $95.46 \%$ ) (Mamiro and Mamiro, 2011; Kimenju et al., 2009; Sharma et al., 2013); P. pulmonarius (BE 75.65\%, PR 1.44\%), P. djamor (BE 19.69\% to 55.79\%, PR 0.36\% to $1.03 \%$ ) (Vega and Franco,2013). In all data cited, BE, PR and Y values are lower, with production cycles longer than those obtained in this study.

\section{Conclusions}

The CP-281 strain was statistically superior, followed by CP-245 and CP-753 strains. These strains exceeded the production on CP-50 strain, which was statistically inferior. However, the four strains reached high BE, Y and PR and are potentially suitable for use in the commercial cultivation or in rural areas with self-consumption production in México.

\section{References}

Gaitán-Hernández, R. and Silva, H.A. (2016). Aprovechamiento de residuos agrícolas locales para la producción de Pleurotus spp., en una comunidad rural de Veracruz, México. Revista Mexicana de Micología, 43, 4347.

Kimenju, J.W., Odero, G.O.M., Mutitu, E.W., Wachira, P.M., Narla, R.D., Muiru, W.M. (2009). Suitability of locally available substrates for oyster mushroom (Pleurotus ostreatus) cultivation in Kenya. Asian Journal of Plant Sciences, 8, 510-514. doi: 10.3923/ajps.2009.510.514.

Mamiro, D.P. and Mamiro, P.S. (2011). Yield and mushroom size of Pleurotus ostreatus grown on rice straw basal substrate mixed and supplemented with various crop residues. Journal of Animal \& Plant Sciences, 10, $1211-1218$.

Martínez- Carrera, D., Larqué-Saavedra, A., Tovar, P.A., Torres, N., Meneses, M.E., Sobal, C.M., Morales, A.P., Bonilla, Q.M., Escudero, U.H., Tello, S.I., Bernabé, G.T., Martínez, S.W., Mayett, Y. (2016). Contribución de los hongos comestibles funcionales y medicinales a la construcción de un paradigma sobre la producción, la dieta, la salud y la cultura en el sistema agroalimentario de México. In: MartínezCarrera D., J. Ramírez Juárez (eds.), Ciencia, tecnología e innovación en el sistema agroalimentario de México. Editorial del Colegio de Posgraduados-AMC-CONACYT-UPAEP-IMINAP, San Luis Huexotla, Texcoco, México, pp. 581-640.

Romero-Arenas, O., Hernández, T.I., Parraguirre, L.J.F.C., Marquez, S.M.N., Amaro, L.J.L. (2013). Evaluación de bagazo de café (Coffea arabica) como sustrato en la producción de Pleurotus ostreatus. Revista Mexicana de Agronegocios, 33, 472-481.

Romero-Arenas, O., Valencia-De Ita, M.A., Rivera-Tapia, J.A., Tello-Salgado, I., Villarreal, E.P.O.A., DamiánHuato, M.Á. (2018). Capacidad productiva de Pleurotus ostreatus utilizando alfalfa deshidratada como suplemento en diferentes sustratos agrícolas. Agricultura, Sociedad y Desarrollo, 15, 145-160.

Royse, D.J., Baars, J., Tan, Q. (2017). Current overview of mushroom production in the world. In: Zied, D.C., A. Pardo-Giménez (eds.), Edible and medicinal mushrooms: Technology and applications. John Wiley and Sons-Blackwell, Nueva York. Pp. 5-13. http://doi.org/10.1002/9781119149446.ch2.

Royse, D.J. and Sánchez, J.E. (2017). Producción mundial de setas Pleurotus spp. con énfasis en países iberoamericanos. In: Sánchez, J.E., D. Royse (eds.). La biología, el cultivo y las propiedades nutricionales y medicinales de las setas Pleurotus spp. El Colegio de la Frontera Sur. Tapachula, Pp.17-25.

Sharma, S., Yadav, R.K.P., Pokhrel, Ch.P. (2013). Growth and yield of oyster mushroom (Pleurotus ostreatus) on different substrates. Journal on New Biological Reports, 2, 03-08.

Vega, A. and Franco, H. (2013). Productividad y calidad de los cuerpos fructíferos de los hongos comestibles Pleurotus pulmonarius RN2 y P. djamor RN81 y RN82 cultivados sobre sustratos lignocelulósicos. Información Tecnológica, 24, 69-78. doi: 10.4067/S0718-07642013000100009. 